\title{
Enerji Alanında Araştırma Üniversiteleri Odaklı Yön-Eylem Belirleme Çalışması
}

\author{
Fikret Müge Alptekin, Dilvin Çebi, Dilan Deniz Demir, Nurdan Karapınar, Merve Uyan, \\ Melih Soner Çeliktaş
}

\author{
Ege Üniversitesi, Güneş Enerjisi Enstitüsü, Izmir, Türkiye \\ ORCID: F.M. Alptekin (0000-0003-2980-5403), D. Çebi (0000-0001-5929-9252), D.D. Demir (0000-0001-9900-8122), \\ N. Karapınar (0000-0001-8301-5897), M. Uyan (0000-0002-0852-1658), M.S. Çeliktaş (0000-0003-0597-5133)
}

\begin{abstract}
Özet
Teknoloji izleme, öngörü çalışmalarının doğal eșleniği olmasının yanında mevcutta ve gelecekte olası tehditlerin bertarafı ve gelişme fırsatlarını artırmak için bilimsel, teknik ve teknolojik ortamın gözlenmesi ve analiz edilmesi olarak ifade edilmektedir. Teknoloji izleme aynı zamanda kurulușların belirli bir alanda içgörü ve rekabet avantajı elde etmek amacıyla teknik bilgilerini sürekli olarak sistematik bir șekilde analiz etmeleri için kullanılan ve temel olarak yayınlanan bilgilerin istatistiksel analizine dayanan bir yöntemdir. Bu çalışma mevcut literatür bilgilerine dayalı enerji alanındaki çalışmaların gözden geçirilmesi ve ilgili yayınlara bağlı olarak araştırma yöntemlerini de içeren teknolojik eğilimin belirlenmesini amaçlamaktadır. Özellikle enerji, yenilenebilir enerji, güç ve yakıt anahtar kelimeleriyle tanımlanan Türkiye adresli son on yılda (2009-2018) yayımlanmış olan makale, patent, tez ve gerçekleștirilen projelerin bibliyometrik yöntem kullanılarak analiz edilmesine odaklanmaktadır. Çalışmada yararlanılan bibliyometrik yaklaşım tüm enerji araștırmalarını değerlendirmek için kullanılmıștır. Gerçekleștirilen çalıșmada ulusal ve uluslararası iș birlikleri de incelenmiștir.
\end{abstract}

Anahtar Kelimeler: teknoloji izleme; bibliyometrik analiz; araştırma üniversiteleri; enerji

\section{A Trajectory Study Focusing on Research Universities Regarding the Field of Energy}

\begin{abstract}
Technology monitoring is a natural conjugate to foresight which is the observation and analysis of scientific, technical and technological environment of economic impacts in order to deduce both current and future threats and increase development opportunities. Technology monitoring is a methodology for organizations to systematically analyze technical information in a continuous way in order to gain insight and competitive advantage in a specific technical domain and is based mainly on statistical analysis of published information. This paper aims to review the existing literature and examine the evolution of such a field so that the research trends can be uncovered, including research methods. The results of an effort to identify the performance of energy, renewable energy, power and fuels research related papers published in Turkey during the last decade (2009-2018) are reported by using a bibliometric approach Bibliometric approaches have been employed in order to assess the field of all energy research. Citation analysis is performed to assess the influence of most productive territories and authors. National and international collaboration was another field investigated in order to be compared with network analysis.
\end{abstract}

Keywords: technology monitoring; bibliometric analysis; research universities; energy

\section{Giriş̧}

Geçiş dönemlerinin tanımlanması zor olsa da içinde bulunduğumuz zaman dilimi bilgi çağından siber fiziksel sistemlere geçiş gibi gizemlerin yanı sıra veri madenciliği, bütün cihazların birbirine bağlanabilme erki, karanlık fabrika dönemi, blockchain teknolojisi, robotik, biyotek-

*Yazışma Adresi / Address for Correspondence:

M. S. Çeliktaş, Email: soner.celiktas@ege.edu.tr

Geliş Tarihi / Received Date: 14.01.2020

Kabul Tarihi / Accepted Date: 09.04.2020

Doi: $10.26701 /$ uad.674544 noloji, big data, nano robot, nörobilim, üssel büyüme, Moore Kanunu, yapay zeka, Gartner Hype Döngüsü, CRISPR, uzay madenciliği gibi kavramların günlük hayatımıza girdiği ve değişen yetkinlikler ile birçok mesleğin ortadan kalkıp dijitalleşmeye yenik düşeceği endişelerini içeren bir dönem yaşanmaktadır.

Tüm bu değişimlerin odak noktasında bulunan üniversiteler, daha önceki dönemlerde endüstriyel gelişmeleri yakından takip etmeleri ve etkileşimleri ile kendilerini yenileyebiliyorlardı. Wissema'nın (Woodfield, 2010) ifade ettiği, 9. yüzyıldan başlayıp 18. yüzyıla kadar sadece eğitim sunan Orta Çağ üniversiteleri yerini günümüze 
kadar faaliyette bulunan ve araștırma geliștirmeye yönelik çalışmaların eskisine göre çok daha fazla ön plana çıktığı ikinci nesil üniversitelere bırakmıștır. Değişen paradigmalar ve yeni yönetim anlayışları ile birlikte daha dinamik bir yapıya bürünme zorunluluğu üniversiteleri özellikle Ar-Ge ekseninde endüstri ile sıkı bir iş birliğine yönlendirmiştir. Wissema'ya göre 21. yüzyılda üniversiteler köklü bir değişime uğramakta ve bilim temelli, tek disiplinli kurumlar olmaktan çıarak, global bilgi merkezi olma yolunda ilerlemektedir.

Birinci nesil üniversiteler bilgiyi arayan ve aristokratların yetiștirildiği belirli zümrelerin ulaşabildiği kurumlarken, ikinci nesil üniversiteler birer bilgi mabedi hissiyatı taşıyordu. Bilgi onlardaydı ve bilgiyi almak isteyen o kapalı kapıları aşmalıydı. Üçüncü nesil üniversiteler ise birer üretim üssüne dönüşmektedir. ABD'de Stanford Üniversitesi, Harvard, MIT, Avrupa'da ise Cambridge, Leuven ve Münih Teknik Üniversitesi bu tip üniversitelerin en iyi örneklerini oluşturmaktadır (Erkut, 2015). Üçüncü nesil üniversitelerde bilim, üniversite ile yüksek teknoloji şirketlerinin iş birliği, kurumsal araştırma kurumları, 'tekno-starter'lar için eğitim ve destek programları, teknoparklar, sponsor şirketlerin güç birliği görülmektedir. Üçüncü nesil üniversiteler büyük bir ekonomik değer ve istihdam yaratabilmektedir.

Değişen dünya içinde, üniversiteler de sürekli değişmekte ve kendilerine yeni misyonlar yüklenmektedir. Birinci (Orta Çağ), ikinci (Humboldt) ve üçüncü (mevcut ve gelecek) üniversite sistemleri arasındaki ana değişken üniversitelerin misyonlarının altında yatan farklılıklardır (Ertüzün, 2017). Üniversiteleri diğer eğitim kurumlarından ayıran en önemli özellik ise araştırma vurgusudur. Araştırma, üniversitenin eğitim ve hizmet ile birlikte üç temel işlevinden biri olarak görülmektedir (Erkut, 2014). Araştırma üniversiteleri, bilimin gelişmesinde büyük rolü olan araştırma çıtıları ile birlikte, eğitim-öğretimden bilgi transferi faaliyetlerine, kamu ve sanayi ile iş birliğinden uluslararası iş birliklerine kadar yansıyan araştırma önceliğine ve araştırma kültürüne sahip üniversiteler olarak tanımlanmaktadır. Araștırma üniversiteleri geliştirdikleri bilgi birikimi, yetiştirdikleri nitelikli işgücü ve yürüttükleri bilgi transferi faaliyetleri ile ekonominin gelişmesinde ve toplumun refahında özel yere sahiptir. Son yıllarda, araștırma üniversitelerinden beklentilerin artması ile birlikte, birçok ülkede getirilen yapısal düzenlemelerle üniversitelerin misyonlarına göre çeşitlenmesine olanak sağlayan yükseköğretim sistemleri oluşturulmuş; araştırma üniversitelerinin gelişmesi için kapsamlı destek programları başlatılmıştır (TAÜG, 2016).

Schumpeter (1934) teknolojik değişim sürecini, yeni fikirlerin ve bilginin üretildiği; buluş, pazarlanabilir ürün ve süreçler içinde yeni fikirlerin geliştirilmesini içeren inovasyon süreci ve bu süreç ve ürünlerin pazara yayllımını içeren süreç olmak üzere üçe ayırmaktadır. Kalkınma sürecinde bilginin topluma yayılımının ana unsurları olarak görülen teknoloji transferi ve inovasyon kavramları sürdürülebilirliğin değișilmez motorları olarak görülmektedir. Araştırma üniversitelerinin inovasyon ekosisteminde anahtar rolü oynayan kişi ve kurumların birbirleriyle olan etkileşimlerinin incelendiği makalede (Brodhag, 2013), gerek yeşil ekonomi kavramı içerisinde istihdam gerekse ekolojik bir dönüşüm için inovasyonun bir gereklilik olduğu ve bu geçişi sağlamak için araştırma üniversitelerinin kilit rol oynadığı ifade edilmektedir. Altbach (2013), bilgi ekonomisi içerisinde araştırma üniversitelerinin rolünü sorgulayan makalesinde, araştırma üniversitelerinin üniversite sisteminin tam merkezinde yer aldığını ve uluslararası ilişkilerde anahtar görevi üstlendiğini belirtmiştir. Araştırma üniversiteleri olarak nitelendirilen ileri düzeyde araştırma yapan üniversitelerin, ülke çapında veya dünya çapında sayıları çok fazla değildir. Bu üniversiteler sayıca az olmalarına rağmen ülkelerinde veya dünyada temel araştırmanın büyük bir çoğunluğunu yürütürler; çok sayıda yüksek lisans, doktora ve doktora sonrası araştırmacı yetiştirirler; üst düzey bilimsel buluşlar daha çok bu üniversitelerde gerçekleşmektedir (Ertüzün, 2017).

Bu çalışmada Yükseköğretim Kurulu tarafından belirlenen ülkemizdeki araştırma üniversiteleri ile aday araştırma üniversitelerinin enerji konusu üzerine yaptıkları araştırmalar; SCI ve SSCI olmak üzere uluslararası endekslerce yayımlanan araștırma makaleleri, YÖK veri sisteminde bulunan lisansüstü tezleri ile Türk Patent Enstitüsü'nün kayıtlarında bulunan patentler baz alınarak son on yıl üzerinden araştırılmış ve bir yol haritası çıkarılmaya çalışılmıştır.

\section{BILIM TEKNOLOJI POLITIKALARI VE ARAŞTIRMA STRATEJILERI}

Geleceği önceden tanımlayıp yönlendirmek amacıyla olasılıkları araştırılan öngörü ufku eğer açık değilse, yukarıdan aşağıya işleyen determinist kontrol aracı bağlamındaki strateji başarılı olamamaktadır. Bugün gelinen noktada öngörü ufkunun karmaşıklığı ile baş edebilmek, olası bir eylem çizgisinin varacağı sonuçları ve ilgili tarafların tepkilerini önceden kestirerek en uygun yolu belirlemek için, 'yukarıdan aşağıya işleyen deterministik yaklaşımlar' yerine dünyayı gözleyerek beklenmeyeni keşfetme ve gelecekteki olayları etkileme gücüne sahip olanların paylaştığı dağıtılmış strateji süreçlerine başvurmak gerektiği bilinmektedir (Durgut, Göker, Üçer, 2001).

Ulusların kendi geleceklerine ilişkin öngörüleri; sosyoekonomik hedefleri bulunmaktadır. Öngörülen hedeflere ulaşabilmek için kullanılan en etkin araç, ulusun bilim, teknoloji ve inovasyondaki yetkinliğidir. Ulusal bilim, teknoloji ve inovasyon stratejileri (politikaları) bu yetkinliği kazanmanın ve sürdürebilmenin yol ve yordamını göstermektedir (Göker, 2008).

Bilim ve teknoloji politikaları, bütün dünyada ülkelerin refah düzeyini doğrudan etkileyen sosyal ve siyasi gidişine yön veren, gelişim ve değişim koşullarını ortaya çıkaran 
türden politikalar olmuştur. Teknolojinin bu etkin işlevi nedeniyle bütün ülkeler teknoloji üretmek, başka ülkeler tarafından üretilen teknolojileri elde etmek, kullanmak ve yaymak için her türlü çabayı göstermektedirler (Yıldız, Ilgaz, Seferoğlu, 2010). Türkiye'de bilim ve teknoloji alanında belirli bir politika izleme arayışı ve ilk politika çalışmaları Planlı Dönem'le birlikte başlamaktadır (Şahin, 1997). Bilimsel faaliyetin yönlendirilmesinde rol alacak ilk kurum olan TÜBİTAK da o tarihlerde kurulmuştur. TÜBİTAK'ın kurulmasını sağlayan 1963-67 dönemini kapsayan Birinci Beş Yıllık Kalkınma Planı'ndaki ilke, izlenecek politikanın ana hatlarını da belirlemektedir. TÜBİTAK'ın araştırmaların plan hedeflerini gerçekleştirecek alanlara yönelmesinde ve buna göre öncelik almasında yardımcı olma misyonu kuruluşuyla birlikte kendisine kanunla verilmiştir (DPT, 1963).

Türkiye'nin ilk kapsamlı bilim ve teknoloji politikası çalışması 1983 yılında gerçekleştirilmiştir. "Türk Bilim Politikası: 1983-2003" başlıklı çalışmanın en önemli sonuçlarından biri, "Bilim ve Teknoloji Yüksek Kurulu” (BTYK) olmuştur. Kurul 1993 yılındaki ikinci toplantısında 1983 dokümanın revize edildiği "Türk Bilim ve Teknoloji Politikası: 1993-2003" belgesini karar altına almıştır. Bu belge esas alınarak yürütülen bir çalışma sonucunda tanımlanan “Bilim ve Teknolojide Atılım Projesi” ile Türkiye'nin bilim ve teknolojideki öncelikli "atılım alanı" ortaya konmuştur. Bu öncelikli alanlar içerisinde yer alan "Çevre Dostu Teknolojiler, Enerji Tasarrufu Sağlayıcı Teknolojiler ve Çevre Dostu Enerji Teknolojileri Üzerinde Odaklanma ve Uygulama Alanlarını Ülke Çapında Hızla Geliştirip/Genişletme" maddesi enerji üzerine yapılacak çalışmalarda ülke için öncelik konusunu belirtmektedir (TÜBİTAK, 2004).

Ar-Ge'de devrim niteliğinde değerlendirilen 8. Kalkınma Planı sonrası hazırlanan ve Avrupa Birliği Çerçeve Programları ile uyumlu hale getirilen 9. Kalkınma Planında Türk Bilim ve Teknoloji Politikasının temel amacı özel sektörün inovasyon-yenilik yaratma yeteneğinde artış olarak tanımlanmaktadır. Kalkınma planında, rekabet gücünün artırılmasında üniversite ve iş dünyası arasındaki iş birliğine dikkat çekilmekte, özel sektör bünyesinde araştırmacıların görev yapmasının özendirileceği, özel sektörün öncelikli alanlarda araştırma enstitüleri ve araştırma merkezleri kurmasının destekleneceği dile getirilmektedir. Öncelikli alanlara ilişkin değerlendirmede ise; nanoteknoloji, biyoteknoloji, nükleer teknolojiler, hidrojen ve yakıt pili teknolojileri, yaşam kalitesinin yükseltilmesine yönelik sağlık araştırmaları, bilgi ve iletişim teknolojileri, savunma ve uzay teknolojileri, ülke içindeki kaynakların katma değere dönüşümü için Ar-Ge faaliyetleri ve sanayi politikasının öncelik verdiği sektörlerdeki çalışmaların öncelikle destekleneceği vurgulanmaktadır (Çeliktaş, 2009).

TÜBİTAK tarafından 2004 yılında hazırlanan Ulusal Bilim ve Teknoloji Politikaları 2003-2023 Strateji Belgesinde yenilenebilir enerji kaynakları potansiyelinin yüksek olması ve yeni enerji teknolojilerinde yararlanılabilecek stratejik kaynakların varlığı Türkiye'nin güçlü yanı olarak ifade edilirken, yeni enerji türlerinin ve enerji alanında yeni teknolojilerin ortaya çıkması ile Türkiye'nin bu alanların gelişimine katkıda bulunarak üstünlük kazanma ihtimalinin ise bir firsat olacağı ifade edilmektedir (TÜBİTAK, 2004).

Bilim ve Teknoloji Yüksek Kurulu'nun (BTYK, 2013) 26. toplantısında enerji öncelikli alanına yönelik çok önemli kararlar alınmıştır. Buna göre;

- Yerli Termik Santral Tasarım ve İmalat Kabiliyetinin Geliştirilmesi (MILTES),

- Hidroelektrik Enerjisi Teknolojilerinin Geliștirilmesi (MİLHES),

- Rüzgâr Enerjisi Santrali Teknolojilerinin Geliştirilmesi (MİLRES),

- Güneş Enerjisi Teknolojilerinin Ülkemize Kazandırılması (MİLGES),

- Termik Santral Baca Gazı Arıtma Teknolojilerinde Yerli Tasarım ve İmalat Kabiliyetinin Geliştirilmesi (MILLAS),

- Kömür Gazlaştırma ve Sıvı Yakıt Üretimi Teknolojilerinin Geliştirilmesi ve

- Enerji Verimliliğinin Artırılması Çalışmaları

öncelik kazanmıştır.

Alınan bu kararlar doğrultusunda enerji öncelikli alanındaki araştırma ekosistemi şekillenmeye başlamıştır.

\section{YENI NESIL ÜNIVERSITELER VE ARAŞTIRMA ÜNIVERSITELERI}

Günümüzde üniversitelerin köklü bir değişime uğrayarak bilim temelli ve tek disiplinli kurum yapısından, küresel bilgi merkezi olma yolunda ilerledikleri gözlenmektedir. Değișen toplum yapısı ve yeni teknolojilere ulaşmanın getirdiği öncelikler yeni nesil üniversite kavramının ortaya atılmasını sağlamıştır.

Bologna'dan günümüze üniversitelerde yaşanan değişimlere bakıldığında, özellikle Orta Çağ üniversitelerinin temel misyonunun sadece eğitim olduğu (Anameriç \& Rukanci, 2009). 17. yüzyıl sonrasında ruhban sınıfının hâkimiyetinden çıkarak, sadece aristokrat ailelerin çocuklarının dâhil olabildiği kurumlar haline gelmekte ve 19 . yüzyılda üniversitelerin topluma açılımının yansımaları görülmektedir. Wilhelm von Humbolt'un gerçekleştirmiş olduğu üniversite reformu, bilim ve eğitim birlikteliği fikrine dayanmaktadır. Humbolt'a göre bilginin korunması ve iletilmesi kadar, üretilmesinin de üniversitenin sorumluluğunda olduğu ve bunun için özgür bir ortam gerekliliği söz konusudur (Alanyall, 2007; Reed, 2004).

Yeni üniversite yaklaşımını benimseyen Amerikan Üniversiteleri, eğitim, araştırma ve toplumsal fayda yönünde 
çalışmalara odaklanmıştır. Bu amaçlarla kurulan büyük araştırma üniversiteleri, modern bir endüstri toplumu yaratmak için gerekli olan teknik uzmanlık ve temel bilgilerin geliştirilmesini sağlayacak şekilde çalışmalar yürütmeye odaklanmışlardır (Alanyalı, 2011; Brubacher \& Willis, 1997).

Soğuk savaş dönemi olarak adlandırılan dönemde araştırma üniversiteleri devlet gölgesinde büyümelerini sürdürmüș ve özellikle enerji, savunma, sağlık, uzay araștırmaları ve ekonomik büyüme gibi ulus devletler için temel konularda araştırmalara eğilmişlerdir (Alanyall, 2007; Solberg \& Geiger, 2010).

Wissema tarafından ortaya atılan "Üçüncü Nesil Üniversite" kavramı, "Bilgi Çağı", "Bilgi Toplumu" gibi kavramlar sonrası hayat bulmuş ve bu kavramlarla birlikte sadece ulus devletlere hizmet eden anlayıș uluslararasılaşma yoluna girmiştir (Alanyal, 2011; Druker, 1999; Beales \& Kerr, 1973). Üniversiteler sadece bilgi üreten değil bunu aktaran ve ticari değer yaratan bir yapıya dönüşmektedir (Alan, 2016).

\subsection{Girişimci ve Yenilikçi Üniversite Endeksi}

Ülkemizde ilk defa Bilim, Sanayi ve Teknoloji Bakanlığı tarafından 2012 yılında açıklanan bu endeks, Bilim ve Teknoloji Yüksek Kurulu'nun 23. toplantısında alınan "Üniversitede yenilikçiliğin ve girișimciliğin tetiklenmesi amacıyla politika araçlarının geliștirilmesi” kararı kapsamında olușturulmuș ve endekse "Girișimci ve Yenilikçi Üniversite Endeksi” adı verilmiştir. Endeks bir eğitim, başarı veya kalite sıralaması değildir. Her yıl düzenli olarak oluşturulması planlanan endeks 5 grupta toplanmış 23 kriterden oluşmaktadır (TÜBİTAK, 2012). Çalışmaya yeni olan üniversiteler ve öğretim üyesi sayısı 50'nin altında olanlar dâhil edilmemektedir.

Tablo 1. Girişimci ve Yenilikçi Üniversite Endeksi'ne göre araştırma üniversitelerinin yıllar içindeki durumlar

\begin{tabular}{|l|c|c|c|c|c|c|c|}
\hline \multicolumn{1}{|c|}{ Üniversiteler } & $\mathbf{2 0 1 2}$ & $\mathbf{2 0 1 3}$ & $\mathbf{2 0 1 4}$ & $\mathbf{2 0 1 5}$ & $\mathbf{2 0 1 6}$ & $\mathbf{2 0 1 7}$ & $\mathbf{2 0 1 8}$ \\
\hline Ankara Üniversitesi & 23 & 26 & 29 & 32 & 22 & 28 & 18 \\
\hline Boğaziçi Üniversitesi & 6 & 4 & 3 & 3 & 5 & 5 & 5 \\
\hline Erciyes Üniversitesi & 13 & 21 & 21 & 13 & 14 & 18 & 17 \\
\hline Gazi Üniversitesi & 15 & 12 & 16 & 18 & 21 & 21 & 13 \\
\hline Gebze Teknik Üniversitesi & 9 & 13 & 12 & 11 & 7 & 3 & 7 \\
\hline Hacettepe Üniversitesi & 11 & 10 & 14 & 14 & 17 & 16 & 8 \\
\hline İstanbul Üniversitesi & 35 & 36 & 32 & 31 & 30 & 32 & 12 \\
\hline İstanbul Teknik Üniversitesi & 5 & 5 & 7 & 6 & 15 & 4 & 2 \\
\hline İzmir Yüksek Tek. Enstitüsü & 7 & 6 & 9 & 8 & 9 & 8 & 9 \\
\hline Orta Doğu Teknik Üniversitesi & 2 & 1 & 1 & 2 & 2 & 2 & 1 \\
\hline Çukurova Üniversitesi* & 20 & 17 & 18 & 22 & 28 & 31 & 27 \\
\hline Ege Üniversitesi* & 12 & 14 & 15 & 15 & 13 & 14 & 10 \\
\hline Selçuk Üniversitesi* & 16 & 11 & 10 & 12 & 12 & 17 & 19 \\
\hline Bursa Uludağ Üniversitesi* & 25 & 29 & 19 & 19 & 24 & 20 & 22 \\
\hline Yıldız Teknik Üniversitesi* & 19 & 15 & 11 & 10 & 10 & 10 & 6 \\
\hline *Aday Üniversiteler & & & & & & & \\
\hline Kaynak: TÜBiTAK & & & & & & \\
\hline
\end{tabular}

Girișimci ve Yenilikçi Üniversite Endeksi'ni olușturan 5 boyut ve bu boyutların yüzdesel ağırlıkları parantez içerisinde aşağıda verilmektedir;

1. Bilimsel ve Teknolojik Araştırma Yetkinliği (\%20)

2. Fikri Mülkiyet Havuzu (\%15)

3. İș birliği ve Etkileşim (\%25)

4. Girişimcilik ve Yenilikçilik Kültürü (\%15)

5. Ekonomik Katkı ve Ticarileşme (\%25)

Endeksi oluşturacak bu veriler, TÜBİTAK, Bilim, Sanayi ve Teknoloji Bakanlığı, Kalkınma Bakanlığı, YÖK, TTGV, TÜBA, TPE, Üniversiteler, KOSGEB tarafından sağlanacak şekilde organize edilmektedir.

2012 yılından günümüze oluşturulan endekste araștırmaya konu olan üniversite ve aday üniversitelerin yllara göre sıralamaları Tablo 1.de verilmektedir.

\subsection{Araştırma Üniversiteleri}

Günümüzde bölgesel rekabetçilik küresel yaklaşımların gölgesinde sürdürülmektedir. Küresel rekabet içerisinde bilgi ve sosyal sermaye gibi maddi olmayan varlıklar yön belirleyen ve ekonomik gelișmelerin motoru durumundadırlar. Bölgesel gelişmelerde bilgi, kalkınmanın en önemli unsuru olarak yerini almaktadır. Bu durumda bilgi, inovasyon, teknoloji ve öğrenmenin rollerinin tekrar gözden geçirilmesi gerekmektedir (Lukovics \& Zuti, 2015; Lukovics \& Zuti, 2017). Çağdaş bir üniversitenin başlıca özellikleri arasında gösterilen (Bolay, 2011), çağın gelişmelerini, dönüşümlerini iyi takip eden, bu konuda sağlam veri toplayan ve bunların ışığında küresel gelişmelerle uyumu doğru olarak sağlayacak tedbirleri alan ve uygulamaya koyan bir yapıdan bahsedilmektedir. Aksi takdirde çağa yetişmek ve de 'çağa yön vermek' gibi çok yüksek bir ideale ulaşmanın objektif olmayacağı düșünülmektedir. Toplumun bugünün üniversitelerinden beklentileri, daha geniş ve karmașıktır. Üniversiteler mali ve insan kaynaklarını toplumun taleplerine cevap verebilmek için dengelemek zorundadırlar. İşgücü piyasasının talepleri ve teknolojik yenilik çoğu zaman değişimi tetikleyen ana faktörler olarak görülebilir; artan küresel rekabet değişimin halen devam ettiğinin bir kanıtıdır.

Goldstein, Maier ve Luger (1995) üniversite çıtılları üzerine bir sistem geliştirme çalışmasında bulundular. Buna göre sistemin odağında geleneksel anlamda üniversite çıtılarından daha geniş bir kavram olan yetenek ve bilgi bulunmaktaydı. Önerilen sistemin ana çatısı bilgi yaratma ile bilgi altyapısı, teknolojik inovasyon ve teknoloji transferini ayırt etme üzerine kurgulanmıştı. Bu çalışmayı daha öteye götüren Hill ve Lendel'e göre (2007) üniversite, başlıca 7 üründen oluşan çok çıktılı bir endüstri olarak görülmektedir. Bu ürünler, eğitim, sözleşmeli araştırma, kültürel çıktılar, eğitimli çalışan, teknoloji yayılımı, yeni bilgi ve yeni ürün ve endüstriler olarak özetlenmektedir. Günümüzde üniversitelerin sadece eğitim-öğretim ve araştırma merkezleri olarak değil aynı zamanda ekono- 
mik büyümenin itici güçleri, toplumların, devletlerin ve uluslarının teknik yönlendiricileri ve yeni öğrenme biçimlerinin geliştirilmesine yönelik merkezler olması da beklenmektedir. Üniversiteler eğitim ve öğretim faaliyetleri ile bilgi transferini, araştırma ile bilginin üretilmesini ve toplumsal katkı ile de bilimin kullanılmasını sağlamaktadırlar. Araştırma üniversitelerinin, diğer kurum ve kuruluşların aksine bilginin üretilmesi, transfer edilmesi ve kullanılması faaliyetlerinin tümünü etkin ve verimli bir şekilde yapması beklenmektedir (Ertüzün, 2017).

Araştırma üniversiteleri, bilimin gelişmesinde büyük rolü olan araştırma çıktıları ile birlikte, eğitim-öğretimden bilgi transferi faaliyetlerine, kamu ve sanayi ile iş birliğinden uluslararası iş birliklerine kadar yansıyan araştırma önceliğine ve araştırma kültürüne sahip üniversiteler olarak tanımlanmaktadır. Araştırma üniversiteleri geliştirdikleri bilgi birikimi, yetiştirdikleri nitelikli işgücü ve yürüttükleri bilgi transferi faaliyetleri ile ekonominin gelişmesinde ve toplumun refahında özel yere sahiptir. Son yıllarda, araştırma üniversitelerinden beklentilerin artması ile birlikte, birçok ülkede getirilen yapısal düzenlemelerle üniversitelerin misyonlarına göre çeşitlenmesine olanak sağlayan yükseköğretim sistemleri oluşturulmuş; araştırma üniversitelerinin gelişmesi için kapsamlı destek programları başlatılmıştır (TAÜG, 2016).

Türk Araştırma Üniversiteleri Güç Birliği'ne göre araştırma üniversiteleri;

- Yalnızca araştırma alanında değil, eğitim-öğretim ve bilgi paylaşımı faaliyetlerinde de mükemmeliyete sahip,

- Uluslararası düzeyde tanınırlığı olan, yeterli genişliğe ve derinliğe sahip araştırma faaliyetleri yürüten,

- Farklı disiplinlerden araştırmacıların bir arada disiplinler arası çalışmalar yürütebildiği,

- Araştırmacı yetiştirme programları ve özellikle güçlü doktora programları olan,

- Üstün nitelikli lisans ve lisansüstü eğitim programlarına sahip,

- Evrensel etik değerleri göz önünde bulunduran,

- Araştırmacıları ve öğretim üyeleri bilimsel ve akademik özgürlüğe sahip olan,

- Farklı görüş ve yaklaşımlara toleranslı ve teşvik edici yaklaşımın bulunduğu,

- Kendi önceliklerini ve stratejik yol haritalarını belirleyebilen ve buna uygun seçimleri yapabilen,

- Eğitim-öğretim ve araştırma faaliyetleri ile toplumsal sorunların çözümüne katkıda bulunan,

- Araştırma üniversitesi olma misyonu ile birlikte, topluma karsı sorumluluklarını da yerine getiren üniversitelerdir.

Ülkemizde araştırma üniversitesi olmak için 58 devlet üniversitesi başvuruda bulunmuştur. İlk aşamada dünyadaki Araştırma Üniversiteleri kriterleri ile nesnel göstergelere göre puan hesaplaması yapılmıştır. Bu göstergeler; SCI indeksli yayın sayısı, uluslararası iş birliği ile yapılan SCI indeksli yayın sayısı, bilimsel yayın puanı, atıf sayısı, proje sayısı ve proje bütçesi, uluslararası iş birliği ile gerçekleşen proje fon bütçesi, doktora mezun sayısı, patent sayısı, TÜBA ve TÜBİTAK ödüllü öğretim üyesi sayısı, TÜBİTAK destekli TTO bulunup bulunmadığı ve YÖK 100/2000 Doktora Burs Programı katılımı olarak tanımlanmış ve bu aşama sonunda ilk 25 üniversite belirlenmiştir. İkinci aşamada başvuran kurumun "Araştırma Üniversitesi Olma Talebi Kapsamında Hazırlamış Olduğu Öz Değerlendirme Raporu” dikkate alınmıştır. Bu aşama sonunda 19 üniversite seçilmiştir. Üçüncü aşama ise Bilim, Sanayi ve Teknoloji Bakanlığı, Kalkınma Bakanlığı, TÜBİTAK, Kalite Kurulu, devlet ve vakıf üniversite temsilcilerinden oluşan bir jüri, rektörler ve üniversitelerin üst yönetimi ile bir mülakat gerçekleştirilmiş ve süreç tamamlanmıştır. Buna göre araştırma üniversiteleri ve aday üniversiteler: Ankara Üniversitesi, Boğaziçi Üniversitesi, Erciyes Üniversitesi, Gazi Üniversitesi, Gebze Teknik Üniversitesi (GTÜ), Hacettepe Üniversitesi, İstanbul Üniversitesi, İstanbul Teknik Üniversitesi (İTÜ), İzmir Yüksek Teknoloji Enstitüsü ve Orta Doğu Teknik Üniversitesi (ODTÜ), Çukurova Üniversitesi, Ege Üniversitesi, Selçuk Üniversitesi, Bursa Uludağ Üniversitesi, Yıldız Teknik Üniversitesi olarak belirlenmiştir. Bu üniversitelerin 2017-2018 yıllarına ait performans bilgileri Tablo 2'de verildiği şekildedir (YÖK, 2018).

Tablo 2. Araştırma ve Aday Araştırma Üniversitelerin 2017-2018 performansları

\begin{tabular}{|c|c|c|c|}
\hline \\
\hline \multicolumn{2}{|l|}{2017} & \multicolumn{2}{|l|}{2018} \\
\hline Üniversite & Puan & Üniversite & Puan \\
\hline ODTÜ & 69,54 & ODTÜ & 73,52 \\
\hline Boğaziçi Üniversitesi & 55,41 & Boğaziçi Üniversitesi & 59,29 \\
\hline IYTE & 53,76 & IYTE & 56,93 \\
\hline ITÜ & 53,09 & ітÜ & 54,93 \\
\hline Hacettepe Üniversitesi & 38,39 & Hacettepe Üniversitesi & 41,98 \\
\hline GTÜ & 36,63 & YTÜ* & 41,05 \\
\hline YTÜ* & 32,86 & İstanbul Üniversitesi & 39,24 \\
\hline İstanbul Üniversitesi & 32,58 & GTÜ & 38,49 \\
\hline Ankara Üniversitesi & 27,88 & Ankara Üniversitesi & 37,25 \\
\hline Bursa Uludağ Üni.* & 25,89 & Erciyes Üniversitesi & 29,22 \\
\hline Ege Üniversitesi* & 24,44 & Ege Üniversitesi* & 25,92 \\
\hline Erciyes Üniversitesi & 22,93 & ïÜ-Cerrahpaşa & 25,48 \\
\hline Gazi Üniversitesi & 22,04 & Gazi Üniversitesi & 25,43 \\
\hline Çukurova Üniversite* & 19,81 & Bursa Uludağ Üni.* & 24,50 \\
\hline \multirow[t]{2}{*}{ Selçuk Üniversitesi* } & 15,63 & Çukurova Üniversite* & 21,15 \\
\hline & & Selçuk Üniversitesi* & 19,66 \\
\hline
\end{tabular}

*Aday Üniversiteler

Kaynak: YÖK

Gerçekleştirilen bu çalışmada ülkemizde YÖK tarafından belirlenmiş 10 adet araştırma üniversitesinin yanında 5 adet yedekte bulunan aday araştırma üniversitesinde "enerji” üzerine yapılan çalışmaları ve bu çalışmaların 
odak noktalarının belirlenmesi ile hangi yöne doğru bir değişim geçirdiğinin bulunmasına yöneliktir. Özellikle enerji, yenilenebilir enerji, güç ve yakıt anahtar kelimeleriyle tanımlanan Türkiye adresli son on yılda (2009-2018) yayımlanmış olan makale, patent, tez ve gerçekleştirilen projelerin bibliyometrik yöntem kullanılarak analizine odaklanılmaktadır.

\section{YÖNTEM}

Teknoloji izleme, kuruluşların belirli bir teknik alanda içgörü ve rekabet avantajı elde etmek amacıyla teknik bilgileri sürekli ve sistematik olarak analiz etmeleri için bir yöntemdir ve temel olarak yayın, patent, web üzerinden yazılı ve görsel medyanın da kullanıldığı bilgilerin istatistiksel analizine dayanmaktadır (Arman, Hodgson, Gindy, 2006). Bibliyometrik terimi eş zamanlı olarak sırasıyla Pritchard (1969), Nalimov ve Mulchenko (1971) tarafından kullanılmaya başlanmıştır. Pritchard bibliyometrik terimini, kitap ve diğer iletişim araçlarına uygulanan matematiksel ve istatistiksel bir yöntem olarak tanımlarken, Nalimov ve Mulchenko bir enformasyon süreci içerisinde bilimsel görünümün analizi ile ilgili niceliksel yöntemlerin tamamının uygulanması olarak tanım yapmışlardır (Patra, Bhattacharya, Verma, 2014).

\subsection{Yayın İzleme}

Bu çalışma kapsamında gerçekleştirilen analizde Şekil 1'de gösterildiği gibi son on yılda (2009-2018 yılları arasında) yayımlanan SCOPUS veri tabanındaki SCI ve SSCI'e girmiş ‘Turkey' adresli yayınlar, YÖK veri tabanında bulunan tezler ve TPE veri tabanında bulunan patentler ve ULAKBIM veri tabanında bulunan gerçekleştirilmiş TÜBİTAK projeleri değerlendirilmekte ve söz konusu belgeler nicelik ve içeriksel özellikleri açısından incelenmektedir. Gerçekleştirilen çalışmada elde edilen araştırma verilerinin değerlendirilmesinde bibliyometrik analiz tekniğinden yararlanılmıştır. Bibliyometrik analiz yapılan çalış- malarda, VOSviewer (Perianes-Rodriguez, Waltman, van Eck, 2016) adı verilen ve bu amaç için geliştirilmiş olan yazılımdan yararlanılmıștır. Söz konusu teknik kullanılırken, genelde tek başlarına pek bir anlam ifade etmeyen veriler bir araya getirilerek yorumlanmakta ve yığın verilere dayanan çeşitli çıkarsamalar yapılmaktadır (Çeliktas, 2009; Çeliktaş, Sevgili, Koçar, 2009). Scopus veri tabanında yer alan 'Turkey' adresli YÖK tarafından belirlenmiş araştırma ve aday araştırma üniversitelerin başlık, özet ve anahtar kelimeleri içerisinde "energy", "renewable energy", "power" ve "fuel” (enerji, yenilenebilir enerji, güç ve yakıt) anahtar kelimeleri kullanılarak yapılan araştırma sonucu elde edilen veriler analiz edilmiştir. Doküman tipi olarak sadece araştırma makaleleri seçilmiştir.

Elde edilen verilerin toplanması ve değerlendirilmesinde Access, Microsoft Excel ve VOSviewer yazılımlarından yararlanılmıştır.

\subsection{Tez İzleme}

Araştırma kapsamında incelenen tezler Yüksek Öğretim Kurulu Başkanlığı Ulusal Tez Merkezi'nin https://tez.yok. gov.tr/UlusalTezMerkezi/ adresinden elde edilmiş ve incelenmiştir.

\subsection{Proje İzleme}

Araştırma ve Aday Araştırma Üniversiteleri'ne ait geçmiş yıllarda gerçekleştirilen TÜBİTAK kaynaklı projeler https://rdizin.gov.tr/search/search.xhtml?resume adresi ile YÖK akademik https://akademik.yok.gov.tr/AkademikArama/ adresinden incelenmiştir.

\subsection{Patent İzleme}

İlgili üniversitelere ait patentler Türk Patent Enstitüsü'nün http://online.turkpatent.gov.tr/EPATENT/servlet/PreSearchRequestManager ve https://akademik.yok. gov.tr/AkademikArama/ internet sayfalarından araştırılmiştır.

\section{Araştırma Yöntemi}

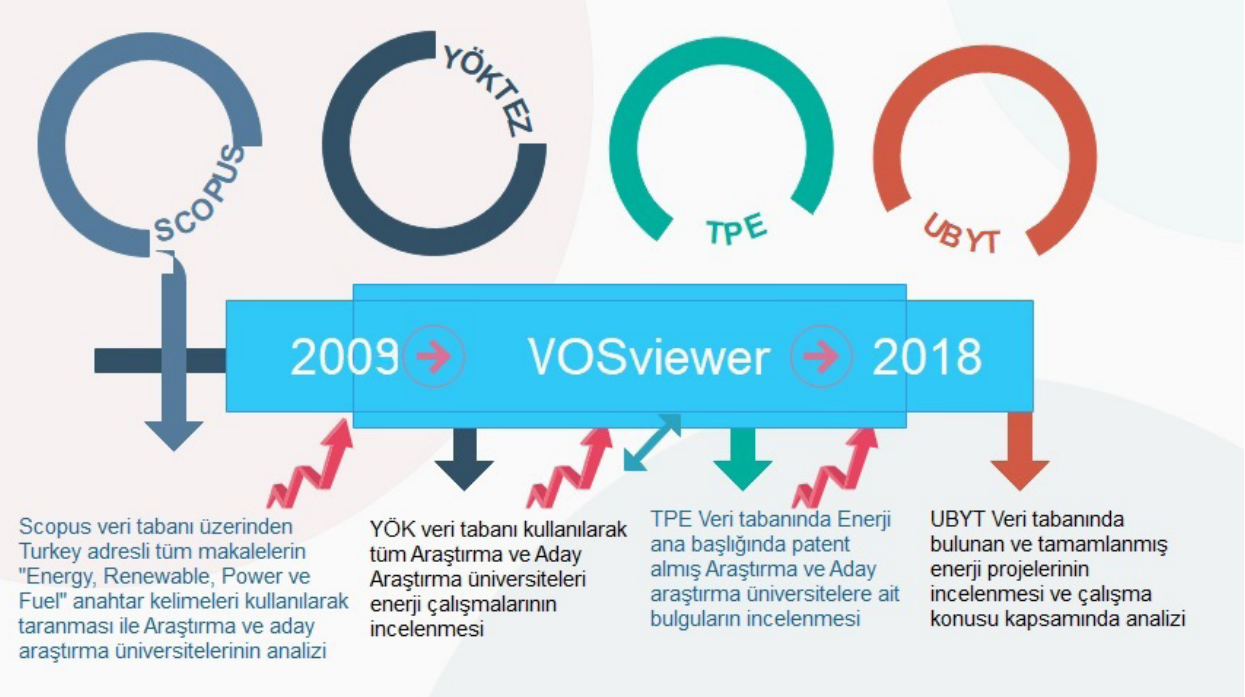

Şekil 1. Araştırma Yöntemi Kısa Gösterimi 


\section{SONUÇLAR}

\subsection{Yayın İzleme Sonuçları}

Çalışmaya konu edinen yayınlar Scopus veri tabanından her bir üniversiteye özel olarak araştırılmış ve VOSviewer programı üzerinden değerlendirilmiştir. Gerçekleştirilen yayınlara yönelik olarak program üzerinde en göze çarpan çalışmalar Tablo 3'de üniversiteler bazında özetlenmiştir. Araştırmaya konu edinilen tüm üniversitelerin enerji konularındaki araştırmalarının genel görünümü ise Şekil 2'de verilmektedir.

Tablo 3. VOSviewer Üzerinden Yayın Değerlendirmeleri

Üniversiteler Enerji araştırmalarında öne çıkan konu başlıkları

Ağırlıkı olarak birbirinden bağımsız enerji depolamaya

Ankara Ü. yönelik çalışmalar öne çıkmaktadır. Aktif karbona bağlı yarı iletken çalışmalarının da ağırıı kazandığı görülmektedir.

Enerji verimliliği, kablosuz sensör sinir ağlarının yanı sıra mikrokanal modelleme, bulanık mantık, biyogaz metan ve sentez gazlarının ağırlıklı olarak çalışıldığı görülmektedir.

Boğaziçi Ü. Bunların yanında araştırmalarda ayrıca yapay sinir ağları, genetik algoritmalar, iklim değişikliği, güneş faaliyetlerinin öne çıktığı görülmektedir.

Biyoyakıtlar, biyodönüşüm, ince film teknolojileri, yanma, Bursa Uludağ termolüminesans, güneş kolektörü, genetik algoritmalar, ekÜ.* $\quad$ serji, rüzgâr türbini, rüzgâr verileri, enerji verimliliği, biyogaz, biyokütle, atık gibi konuların öne çıktığı görülmektedir.

Transesterifikasyon, biyodizel ve dizel motorlar konusundaki çalışmaların yanı sıra hidrojen üretimi, ısıl enerji depola-

ma, elektrokatalist ve rüzgâr konusundaki çalışmalar öne çıkmaktadır. Solar radyasyon, güç kalitesi, sinir ağları yine birbirinden bağımsız olarak son yıllarda özellikle üzerinde durulan enerji araştırmaları olarak karşımıza çıkmaktadır.

Yayınlara yansıyan araștırmalarda ekserji, ekserji analizi, enerji verimliliği, gibi genel konuların yanında yenilenebilir enerji alanında biyokütle, hidrojen üretimi, Fotovoltaik, Ege Ü.* yakıt hücreleri ve jeotermal enerji araştırmalarının son yıllarda yoğunlaştığı görülmektedir. Optimizasyon çalışmalarının yanı sıra biyohidrojen, bor, absorpsiyon, kablosuz sensör ağları gibi yeni konularda da çalışmaların yoğunlaştığı görülmektedir

Yapılan çalışmaların ısı bilimi, elektronik ve fizik alanı etrafında yoğunlaştığı görülmektedir. Malzemelerde termal iletkenlik, termofiziksel özelikler, elektrik iletkenlik, manyetik özellikler, termolüminesans, yakıt hücreleri, nanokristal ince

Erciyes Ü. film teknolojileri, ince film yerine kullanılabilecek malzemelerin yapısal, yüzey, optik ve dielektrik özellikleri gibi konuların yanı sıra son yıllarda hidrojen yakıtlı gaz türbinleri, hidrojen yakıtı, yanma ve görüntüleme teknikleri, süperkapasitör gibi çalışmaların nadiren de olsa öne çıktığı görülmektedir.

Son yıllarda yapılan çalışmalara bakıldığında, talep tahmini modelleme, off-grid ve smart-grid, harmonik güç hesaplama, hibrit yakıt hücreleri, elektrikli araç, enerji depolama, elektrik motorları, Isı pompası, yakıt hücreleri, algler, yenilenebilir enerjinin finansmanı, güneşle kurutma, biyodizel, ISı transferi, enerji ve ekserji analizi, hidrojen üretimi, kombine güç santralı, enerji bağımlılığı gibi konuların öne çıktığı görülmektedir.

Enerji transferi, iletkenlik, yarı iletkenler, nanoparçacık, fotokimya, biyodizel, yakıt hücreleri, hidrojen üretimi, rüzgâr enerjisi, optimizasyon, gazlaştırma, hidroliz, transesterifikasyon, elektrod üretimi, enerji depolama, organik ve likid kristal güneş hücreleri gibi konularda yoğunlaşılmıştır.

Isı transferi, optimizasyon, modelleme, güç kalitesi, karbon-

Hacettepe Ü. dioksit yakalama, görüntüleme, yakıt hücreleri, hidrodinamik ve biyosensör konuları öne çıkmaktadır.

\begin{tabular}{|c|c|}
\hline Üniversiteler & Enerji araştırmalarında öne çıkan konu başlıkları \\
\hline İstanbul Ü. & $\begin{array}{l}\text { Rüzgâr enerjisi, enerji verimliliği, yenilenebilir enerji, ekserji, } \\
\text { biyokütle, yakıt hücreleri, termal enerji depolama, model- } \\
\text { leme, optimizasyon, iletkenlik, hidrojen, enerji tüketimi, } \\
\text { termal iletkenlik, güneş ışığı ışınımı, iyonik iletkenlik, ince } \\
\text { film, ısı pompası, dizel motor, hava kirliliği, enerji politikaları, } \\
\text { kömür, enerji yönetimi, organik güneş hücreleri gibi konular } \\
\text { dikkat çekmektedir. }\end{array}$ \\
\hline ітü & $\begin{array}{l}\text { Rüzgâr enerjisi, yenilenebilir enerjiler, biyokütle, enerji ve- } \\
\text { rimliliği, ekserji, rüzgâr verilerinin analizi, termal enerji depo- } \\
\text { lama, enerji transferi, güneş enerjisi, kapasite faktörü, karar } \\
\text { ağaçları, çok kriterli karar verme mekanizmaları, elektrik } \\
\text { üretimi, eksegoekonomi, dizel motorlar, yakıt hücreleri, li-i- } \\
\text { on piller, LCA, mikrobial yakıt hücreleri, biyogaz, hidrojen } \\
\text { çalışmaları bulunmaktadır. }\end{array}$ \\
\hline IYTE & $\begin{array}{l}\text { Simülasyon, enerji absorblama, gün ışı̆̆ı, enerji verimliliği, je- } \\
\text { otermal enerji, ince film teknolojileri, yanma, dizel, doğalgaz, } \\
\text { iklim değişikliği, enerji performansı, rüzgâr enerjisi, ekserji } \\
\text { çalışmaları göze çarpmaktadır. }\end{array}$ \\
\hline ODTÜ & $\begin{array}{l}\text { Kinetik, karbondioksit emisyonları, yenilenebilir enerji, } \\
\text { hidrojen üretimi, yanma, süperkapasitörler, güneş enerjisi, } \\
\text { optimizasyon, enerji verimliliği, güç kalitesi, konjuge poli- } \\
\text { mer teknolojileri, iletken polimerler, enerji ekonomisi, pv, } \\
\text { karbonnanotüpler, yarıletkenler, güneş ışınımı, piroliz, linyit, } \\
\text { incefilm, atıksu, organik Rankine çevrimi ele alınmıştır. }\end{array}$ \\
\hline Selçuk Ü.* & $\begin{array}{l}\text { Motor performansı, biyodizel, dizel motorlar, antioksidan } \\
\text { aktivite, optimizasyon, mineraller, biyoetanol, doymuş yağ } \\
\text { asitleri, transesterifikasyon, fenolik bileşikler, enzim, güneş } \\
\text { enerjisi, depolama, enerji verimliliği, hidrojen gibi daha çok } \\
\text { yakıtlar ve yanma konuları özelinde çalışmalar yoğunluk ka- } \\
\text { zanmıştır. }\end{array}$ \\
\hline YTÜ* & $\begin{array}{l}\text { Ekserji, dizel motor, yenilenebilir enerji, güneş enerjisi, op- } \\
\text { timizasyon, motor performansı, modelleme, hidrojen, rüz- } \\
\text { gâr, kojenerasyon, yanma, biyodizel, enerji tüketimi, smart } \\
\text { grid, yakıt hücreleri, mikrobiyal yakıt hücreleri, biyokütle, ısı } \\
\text { pompası, gaz türbinleri, eksergoekonomik analiz, piroliz ko- } \\
\text { nuları öne çıkmaktadır. }\end{array}$ \\
\hline
\end{tabular}

Tüm araştırma üniversiteleri ve aday üniversiteler bir arada değerlendirildiğinde ekserji, yenilenebilir enerji, optimizasyon, biyodizel, güneş enerjisi, rüzgâr enerjisi, kinetik, antioksidan aktivite, motor performansı, biyokütle, verimlilik, dizel motor, hidrojen, yanma, kurutma, egzoz emisyonları, termal enerji depolama, ısı pompası, algoritmalar, yüzey yanıt metodu, biyogaz, anaerobik çürütme, metan, kojenerasyon, bulanık mantık gibi konuların çalışıldığı̆ görülmektedir (Şekil 2-Şekil 3).

\subsection{Tez İzleme Sonuçları}

YÖK tez veri tabanı üzerinden, belirlenmiș olan anahtar kelimelerle tez isimlerinde yapılan araștırma neticesinde en çok lisansüstü tez çalışmasının İstanbul Teknik Üniversitesi'nde yapıldığı, bunu Gazi Üniversitesi ve ODTÜ'nün takip ettiği görülmüştür (Şekil 4). Doktora çalışmaları kapsamında Gazi Üniversitesi diğer üniversitelerin bir adım önüne geçmektedir. Yapılan tez çalışmalarının \%23'lük kısmını doktora çalışmaları oluştururken bu çalışmaların \%15'lik kısmı Gazi Üniversitesi'nden gelmektedir. Yüksek Lisans araştırmalarının ise \%21'lik kısmı İTÜ'den gelmektedir. Lisansüstü çalışmalarda belli bir disiplinin üstünlügü görülmezken sosyal bilimlerden enerji üzerine yapılan çalışmaların sayısal olarak azlığı dikkat çekmektedir.

Son yıllarda yapılan tezlere bakıldığında özellikle ekonomi, uluslararası ilişkiler, eğitim ve öğretim, hatta hukuk 


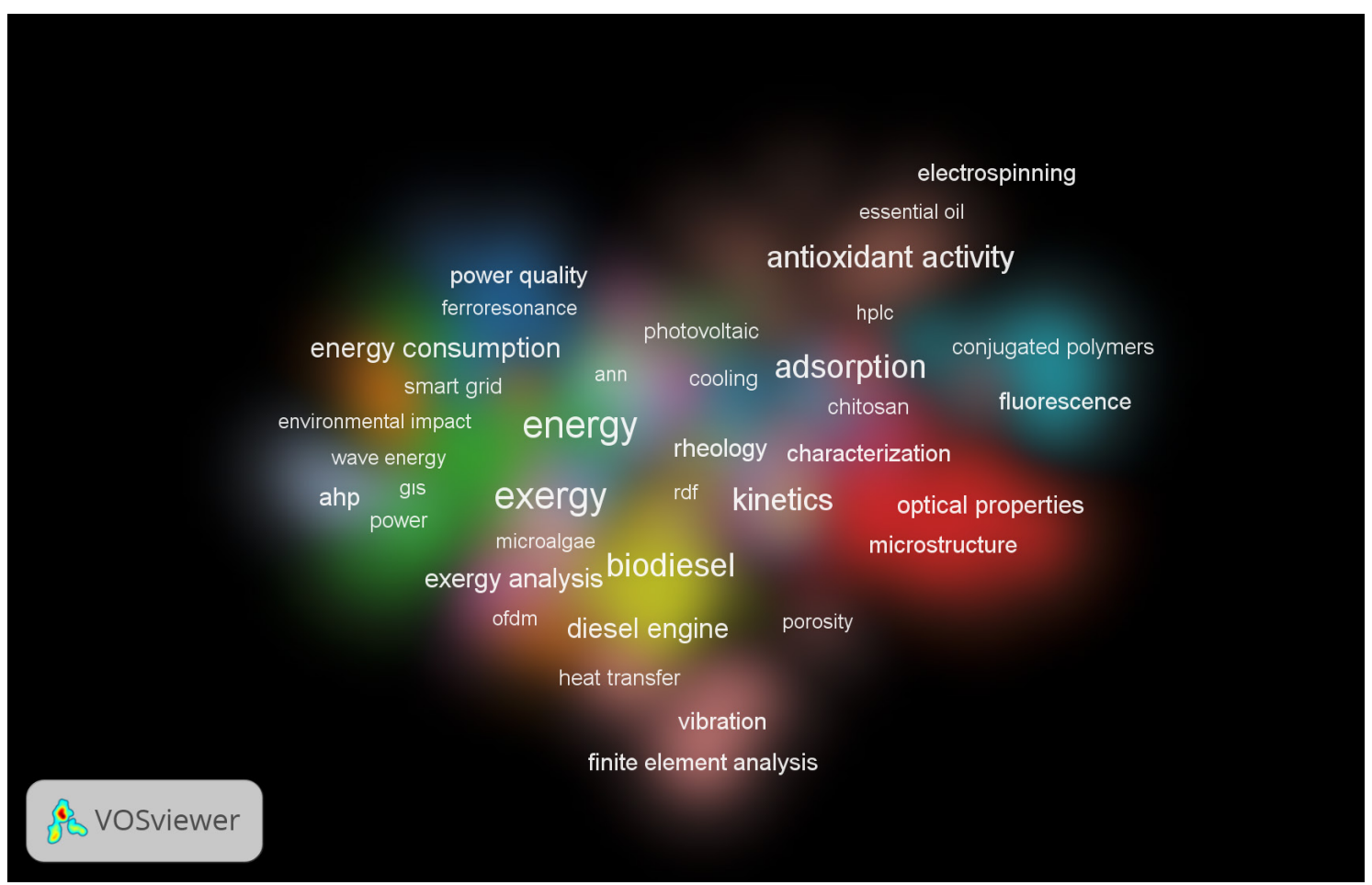

Şekil 2. Araştırma Üniversiteleri Kapsamında Değerlendirilen 15 Üniversiteden Yapılmış Olan Yayınların En Çok Içerdiği Anahtar Kelimeler

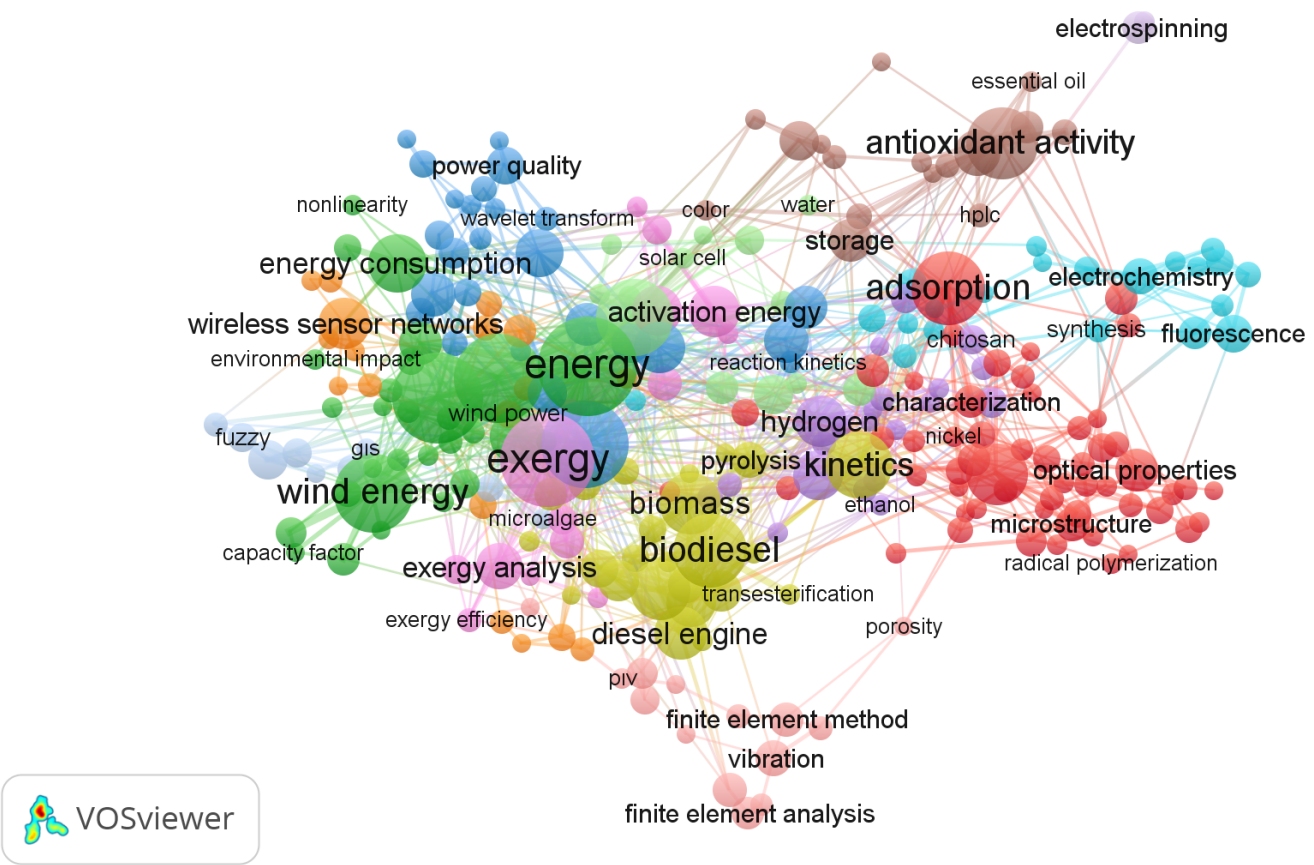

Şekil 3. Araştırma Üniversiteleri Kapsamında Değerlendirilen 15 Üniversiteden Yapılmış Olan Çalışmalarda Geçen Anahtar Kelimelerin Birbirleri ile Olan Ilişkileri

gibi disiplinlerden gelen çalışmalarla araştırma haritasının daha da renklendiği görülmektedir. Geçmiş yıllarda eksiklik olarak ifade edebileceğimiz araştırma desenindeki bu boşluk özellikle 2019 yılında yapılan çalışmalarla giderilmektedir. Bir başka dikkat çekici nokta ise mimarlık alanından yapılan katkılar olarak görülmektedir. Özellikle yeşil ev, kendi kendine yeten mimariler, yapı bileşenleri üzerine yapılan çalışmalar enerji araştırma alanına olumlu katkı yapmakta ve disiplinler arası çalışmayı teşvik etmektedir. Son yıllarda yaşanan ekonomik daralmanın yansıması olarak görünen kaynak kısıtlılığı araştırma konuları üzerinde de etkili olmaktadır. Özellikle araştırmacılar deneysel çalışma yerine modelleme, gelecek projeksiyonu, politikalar, iklim değişikliğinin olumsuz etkileri, karbon piyasaları, enerji yönetimi, enerji verimliliği, ekserji analizi gibi çok kaynak gerektirmeyen çalışmalara yönelmektedir.

\subsection{Proje ve Patent İzleme Sonuçları}

TÜBİTAK tarafindan yayınlanan ve son beş yılı içeren ARDEB istatistikleri (https://www.tubitak.gov.tr/sites/ default/files/18842/9_universiteler_bazinda_ardeb_des- 

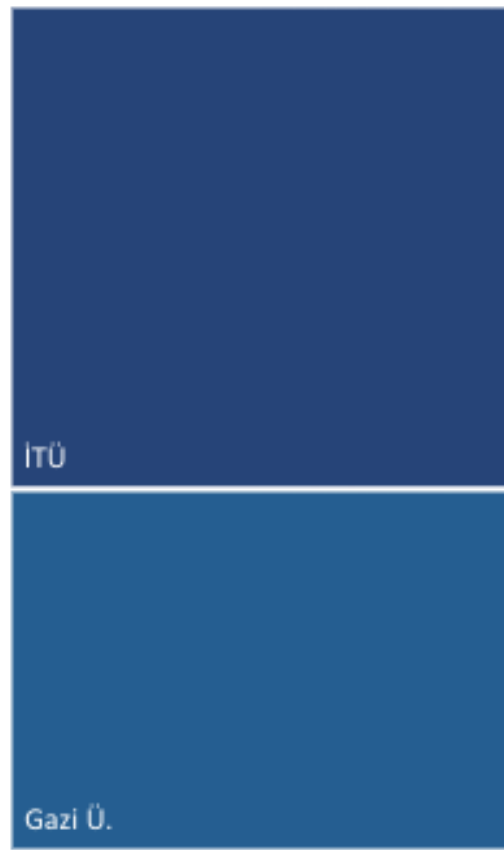
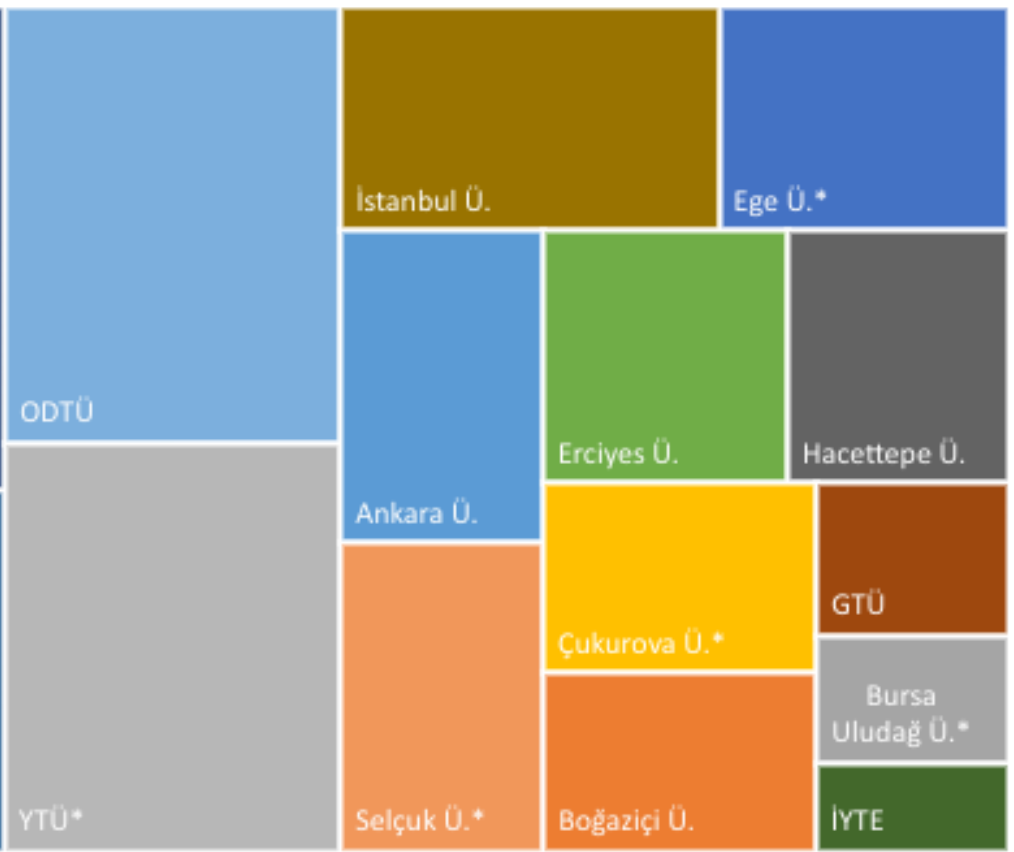

Şekil 4. Araştırma Üniversiteleri Kapsamında Değerlendirilen 15 Üniversiteden Yapılmış Olan Lisansüstü Tez Çalışmalarının Üniversitelere Göre Dağılımı

tek_istatistikleri_2014-2018.pdf) üzerinden yapılan incelemede en çok sayıda proje başvurusu Ege Üniversitesi'nden yapılmış olmasına rağmen en yüksek oranda proje kabulü başarısı ODTÜ’ye aittir. En yüksek fon miktarını alan araştırma üniversiteleri ise ODTÜ, İTÜ, Boğaziçi ve IYTE şeklinde sıralanmaktadır. Bu istatistikler tüm proje konularını içermekte olup sadece enerji alanına yönelik değildir. Enerji alanında yapılmış olan projeler geriye dönük raporlar üzerinden ULAKBİM adresinden incelenebilmektedir. Enerji projeleri raporları incelendiğinde benzer bir tablo görülmektedir. Enerji konusunda en çok proje üreten üniversiteler; İTÜ, Ege, Yıldız Teknik ve ODTÜ olarak görülmektedir. Konu özelinde incelendiğinde hem yayınlarda hem de tezlerde görülen dağ nık bir yapıyla karşılaşılmaktadır. Enerji konusunda hem TÜBİTAK hem de kalkınma planlarında yer verilen ülke öncelikli alanları arasında yer alan yakıt hücreleri, güneş hücreleri, enerji verimliliği, güneş termal sistemler, enerji bitkileri, temiz kömür teknolojileri ve yenilenebilir enerjiler başta olmak üzere birçok başlıkta proje üretildiği görülmektedir. Fakat bu üretimler ne yazık ki patent verilerine yansımamaktadır. Patent üretiminde ODTÜ, İTÜ ve Gazi Üniversitesi öğretim üyelerinin bireysel patentlerde hak sahibi olduğu görülürken çoğunlukla motor, yoğunlaştırıcılı güneş enerjisi toplayıcılar, süperkapasitör, akıllı ev sistemleri, aktif karbon, termoelektrik özellikli materyallerin karakterizasyon, güç kalitesi, güç kontrol cihazları, enerji iletimi, enerji hasatlama, enerji santrallerinde optimal yük dağılımının sağlanması gibi konularda patentleme yapıldığı görülmektedir.

\section{TARTIŞMA}

On Birinci Kalkınma Planında, ülkemizin "yenilikçi teknolojilerin çoğu açısından teknoloji geliştirme ve bu tek- nolojilerin üretken kullanımı konusunda gelişmiş ülkelere göre kısıtlı yeteneklere" sahip olduğu ifade edilmektedir. Ülkemizin teknolojik dönüşüme ayak uydurabilmesi için öncelikli sektör ve alanlarda nitelikli insan kaynağını zenginleştirmesi, teknolojinin işletmelere yayılımını artırması, firmaların organizasyon ve yenilik kabiliyetlerini geliştirmesi, araştırma-geliştirme (Ar-Ge) ve yeniliğin finansmanına yönelik etkin mekanizmaları devreye sokması On Birinci Kalkınma Planı döneminde rekabet gücü kazanması açısından öncelikli hususlar olarak öne çıkmaktadır. Ar-Ge çalışmalarının temelinde üniversiteler olduğu gerçeğinden hareketle araştırma üniversitelerine bu kapsamda oldukça önemli görevler düşmektedir. Gerek araştırma yetkinliği gerekse uluslararasılaşma kapsamında öncü olmaları beklenen araştırma üniversitelerinin bu rekabeti sağlayacak altyapılarını sürekli güncel tutacak kaynaklara olan ihtiyacı mevcut fonlarla sağlayabilmesi oldukça güç görünmektedir.

Onuncu Kalkınma Planı döneminde, Ar-Ge harcamalarının GSYH içindeki payı 2013'te yüzde 0,82 iken 2017'de yüzde 0,96'ya yükselmiştir. Fakat dünya ölçeğinde baktığımızda bu rakamların özellikle gelişmiş ülkelerde \%3 civarı olduğu görülürken İsrail ve G. Kore gibi ülkelerde \%4’ün üzerine çıkmaktadır (Şekil 5).

Kalkınma planında Ar-Ge ve yenilik destek sisteminin odaklı, araştırmadan ticarileştirmeye tüm süreci kapsayan, orta-yüksek ve yüksek teknoloji sektörlerine yönelik olarak farklılaşan ve sektörlerin ihtiyaçlarını ve gelişme potansiyellerini dikkate alan bir yapıya dönüştürüleceği ve bunun için politikalar üretileceği ifade edilmektedir.

Gerçekleştirilen çalışmada görülen ve araştırma üniversitelerimizin enerji konusundaki üretimleri Gartner tarafından üretilen bir Hype-Cycle şekline dönüştü- 


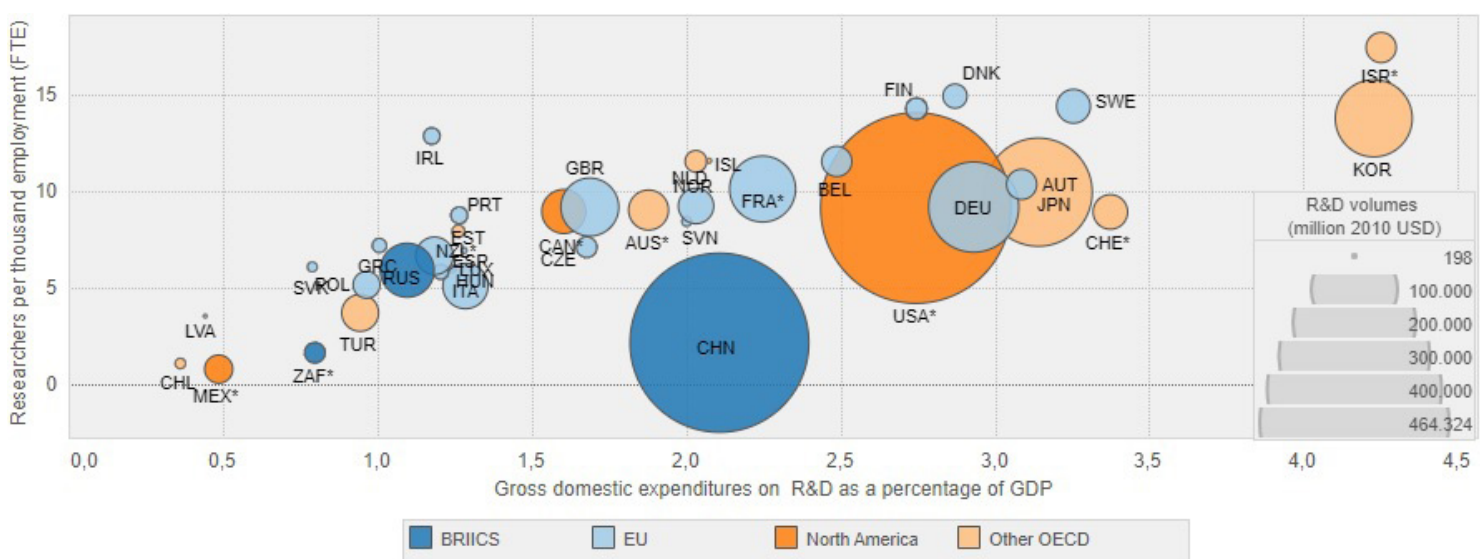

Şekil 5. Dünya Ölçeğinde Brüt Ar-Ge Harcamalarının GSH'ya Oranı Ve Tam Zaman Eşdeğeri Araştırmacı Sayıları (Kaynak: OECD: Https://Www. Oecd.Org/Sti/Inno/Researchanddevelopmentstatisticsrds.Htm)

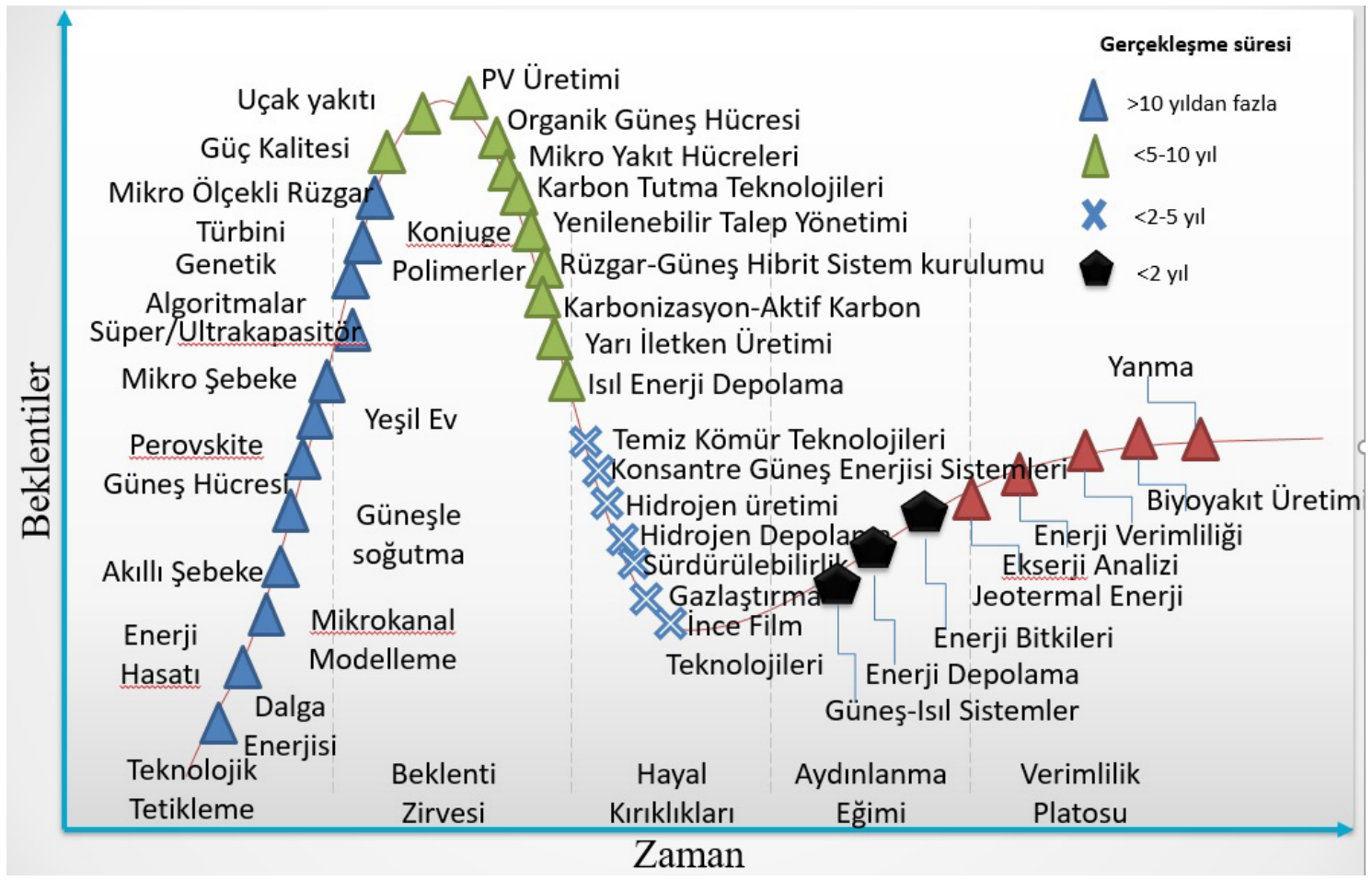

Şekil 6. Araştırma Konularının Olgunlaşma Evrelerine Göre Dağılımı

rüldüğünde enerji araştırma konularının olgunlaşma evreleri Şekil 6’da verildiği gibi ifade edilebilir.

Gerçekleştirilen çalışmada en çok dikkat çeken husus araştırma konularının çeşitliliği ve eşgüdüm eksikliği olmuştur. Hepsi genellikle bir merkezden fonlanmalarına karşılık dağınık bir yapı sergilenmekte ve araştırmaların teknoloji olgunluk seviyeleri çok dikkate alınmaksızın fonlandığı görülmektedir. Öncelikli alanlarda tam olarak bir hedef belirtilmediği gibi ana başlıklar etrafında șekillenen bir araştırma deseni ülkenin kısıtlı kaynaklarının doğru yönlendirilemediğine işaret etmektedir. Yurtdışında doktora yapacak ve sonrasında ülkemizin araştırma alanında beşeri sermayemizi oluşturacak gençlere verilecek burslar (2213) için belirlenmiş olan enerji konusundaki öncelikli alanlar; enerji depolama teknolojileri, enerji verimliliği, güneş enerjisi, kömür teknolojileri ve rüzgâr enerjisi olarak görülmekteyken Cumhurbaşkanlığı Bilim, Teknoloji ve Yenilik Politikaları Kurulu (BTYPK) üyelerinin Eylül ayı içerinde belirledikleri teknoloji öncelik alan- ları içerisinde sadece enerji depolama teknolojilerinin yer alması anlam karmaşasına yol açmaktadır. Tespit edilen bu gibi sorunların giderilmesi ve belirlenen politikaların daha etkin bir şekilde uygulanması açısından bütüncül bir yaklaşım ve uygun altyapı desteğine önem verilmesi bilimsel gelişmeyi olumlu yönde etkileyecek, çalışmaların doğru hedeflere yönelik ilerlemesini sağlayacaktır.

\section{KAYNAKÇA}

Alan, G. \& Alan, E. (2016). Türkiye'de Yeni Nesil Üniversiteler. Maltepe Üniversitesi Illetişim Fakültesi Dergisi, 2, 105-118.

Altbach, P. G. (2013). Advancing the national and global knowledge economy: The role of research universities in developing countries. Studies in Higher Education, 38(3), 316-330.

Anameriç, H. \& Rukanci, F. (2007). Libraries in the middle east during the ottoman empire (1517-1918), International Journal of Libraries and Information Studies, 59 (3), 145-154.

Antalyalı, Ö. L. (2007). Tarihsel Süreç İçerisinde Üniversite Misyonlarının Oluşumu. Süleyman Demirel Üniversitesi Sosyal Bilimler Enstitüsü Dergisi, 6(2), 25-40. 
Antalyalı, Ö. L. (2011). Türkiye Üniversitelerinin Örgütsel Etkililik Boyutları. Süleyman Demirel Üniversitesi Iktisadi ve Idari Bilimler Fakültesi Dergisi, 16 (3), 285-309.

Arman, H., Hodgson, A., Gindy, N. (2006, July, 8-13). Threat and opportunity analysis in technological development. Portland International Conference on Management of Engineering and Technology, PICMET.

Beales, A. C. F., Kerr, C. (1973). The Uses of the University. British Journal of Educational Studies, 21(3), 353.

Bolay, S. H. (2011). Çağdaş Üniversitede Neler Önem Kazanmaktadır?. Yükseköğretim ve Bilim Dergisi, 1(3), 105-112.

Brodhag, C. (2013). Research universities, technology transfer, and job creation: What infrastructure, for what training?. Studies in Higher Education, 38(3), 388-404.

Brubacher, J. S. \& Willis, R. (1997). Higher Education in Transition: A History of American Colleges and Universities. New York: Routledge.

BTYK. (2013). Bilim ve Teknoloji Yüksek Kurulu 26. Toplantısı Yeni Kararlar, Retrieved from http://www.tubitak.gov.tr/ sites/default/files/btyk_26_yeni_kararlar.pdf

Çeliktas, M. S. (2009). Türkiyéde yenilenebilir enerji teknolojilerinin gelecek öngörüsü. (Doktora tezi). Ege Üniversitesi Güneş Enerjisi Enstitüsü, İzmir.

Çeliktaş, M. S., Sevgili, T., Koçar, G. (2009). A snapshot of renewable energy research in Turkey. Renewable Energy, 34, 14791486

Devlet Planlama Teşkilatı (DPT). (1963). Kalkınma Planı Birinci Beş Yll 1963-1967, Retrieved from http://www.sbb.gov. tr/wp-content/uploads/2018/11/Birinci-Beş-Yıllık-Kalkınma-Planı-1963-1967.pdf

Drucker, P. (1999). La Sociedad Poscapitalista. Buenos Aires: Editorial Sudamericana.

Durgut, M., Göker, A., Üçer, A. Ş. (2001). Türkiye için Teknoloji Öngörü Çalışması Model Önerisi. Retrieved from http:// www.inovasyon.org/pdf/AYK.Sabanci.ForesightMay01. pdf,

Erkut, E. (2014). Türkiye'de girişimcilik ve üniversiteler. Retrieved from http://erhanerkut.com/wp-content/uploads/2016/03/TRdeGirisimcilikRev.pdf

Erkut, E. (2015). Türkiye'deki Üniversitelerin Araştırma Çıktıları Üzerine. Retrieved from http://erhanerkut.com/analiz/turkiyedeki-universitelerin-arastirma-ciktilari-uzerine/

Ertüzün, A. (2017). Toplumun İtici Gücü: Araştırma Üniversiteleri. YÖK Yüksek Öğretim Dergisi, 1, 16-19.

Goldstein, H., Maier, G., Luger, M. (1995). The university as an instrument for economic and business development: U.S. and European comparisons, Emerging Patterns of Social Demand and University Reform: Through a Glass Darkly, Dill, D. \& Sporn, B. (Eds.) Emerald Group Publishing Limited.

Göker, A. (2008, Kasım, 21-22). Öngörülen geleceği yaratabilmek: Ulusların bilim, teknoloji ve inovasyon stratejileri / politikaları. Sağlık Bilimlerinde Süreli Yayıncılık 6. Ulusal Sempozyum. Ankara

Hill, E.W. \& Lendel, I. (2007). The impact of the reputation of bio-life science and engineering doctoral programs on regional economic development. Economic Development Quarterly, 21(3), 223-243.
Lukovics, M. \& Zuti, B. (2015). New Functions of Universities in the XXI. Century: "Fourth Generation “ Universities?. Journal Transition Studies Review, 22(2), 33-48.

Lukovics, M. \& Zuti, B. (2017). Successful Universities towards the Improvement of Regional Competitiveness: 'Fourth Generation' Universities, Retrieved from http://dx.doi. org/10.2139/ssrn.3022717

Nalimov, V. V. \& Mulchenko, Z. M. (1971). Measurement of Science. Study of the Development of Science as an Information Process. National Technical Information Service. Virginia: Springfield.

Patra, S. K., Bhattacharya, P., Verma, N. (2014). Bibliometric Study of Literature on Bibliometrics. DESIDOC Bulletin of Information Technology, 26, 27-32.

Perianes-Rodriguez, A., Waltman, L., van Eck, N. J. (2016). Constructing bibliometric networks: A comparison between full and fractional counting. Journal of Informetrics, 10 (4), 1178-1195.

Pritchard, A. (1969). Statistical Bibliography or Bibliometrics?. Journal of Documentation, 25(4), 348-349.

Reed, D. (2004). Universities and the Promotion of Corporate Responsibility: Reinterpreting the Liberal Arts Tradition. Journal of Academic Ethics, 2(1), 3-41.

Schumpeter, J. A. (1934). The Theory of Economic Development: An Inquiry Into Profits, Credit, Interest, and the Business Cycle, England: Routledge.

Solberg, W. U. \& Geiger, R. L. (2010). Research and Relevant Knowledge: American Research Universities since World War II, Academe, American Association of University Professors, 80(1), 56-58.

Şahin, Ş. (1997). Türkiye'de Bilim ve Teknoloji Politikası. İstanbul: Göçebe yayınları.

Türk Araştırma Üniversiteleri Güçbirliği (TAÜG). (2016). Araştırma Üniversiteleri ve Yüksekögretim, Araştırma ve İnovasyonda Uluslararası Rekabet.

Türkiye Bilimsel ve Teknolojik Araştırma Kurumu (TÜBiTAK). (2004). Ulusal Bilim ve Teknoloji Politikaları. 2003-2023 Strateji Belgesi, 2004.

Türkiye Bilimsel ve Teknolojik Araştırma Kurumu (TÜBITAK). (2012). Girişimci ve Yenilikçi Üniversite Endeksi Gösterge Seti [Veri Dosyası]. Retrieved from http://www.tubitak.gov.tr/ sites/default/files/gyue_gosterge_seti.pdf, 2012.

Yıldız, B. \& Ilgaz, H. \& Seferoğlu, S. S. (2010, Şubat, 10-12). Türkiye'de Bilim ve Teknoloji Politikaları: 1963'den 2013'e Kalkınma Planlarına Genel Bir Bakış, Akad. Bilişim'10 - XII. Akademik Bilişim Konferansı, Muğla Üniversitesi, Muğla.

Yükseköğretim Kurulu. (2018). Küresel rekabet ortamında misyon farklılaşması ve ihtisaslaşma toplantısı. YÖK Yüksek Öğretim Dergisi, 7, 103-107.

Woodfield, S. (2010). Towards the Third Generation University: Managing the University in Transition - By J. G. Wissema. Higher Education Quarterly, 64(2), 216-225. 